\title{
Catabolism through the threonine dehydrogenase pathway does not account for the high first-pass extraction rate of dietary threonine by the portal drained viscera in pigs
}

\author{
Nathalie Le Floc'h* and Bernard Sève \\ Joint Research Unit for Calf and Pig Production, INRA 35590 Saint Gilles, France
}

(Received 13 March 2004 - Revised 4 October 2004 - Accepted 15 November 2004)

\begin{abstract}
In pigs the extensive threonine utilization by the splanchnic tissues explains the relative inefficiency of dietary threonine conversion for body protein accretion. Two experiments were conducted to estimate the contribution of the portal drained viscera (PDV) and the liver to threonine metabolism and especially catabolism in growing pigs. In the first experiment, four pigs were surgically prepared for chronic catheter insertion in the portal, hepatic and jugular veins and in the carotid artery. They were continuously infused with L- $\left[1-{ }^{13} \mathrm{C}\right]$ threonine through the jugular catheter. The PDV and total splanchnic viscera (PDV and the liver) extracted 14.3 and $18.8 \%$ of arterial threonine input, respectively. In a second experiment, we studied the metabolism of dietary threonine in the PDV and the liver in six female growing pigs. Animals were surgically prepared as in the first experiment except that L- $\left[1-{ }^{13} \mathrm{C}\right]$ threonine and $\left[{ }^{15} \mathrm{~N}\right] \mathrm{gly}-$ cine were continuously infused in the duodenum for $10 \mathrm{~h}$. Unlabelled and labelled threonine and glycine PDV, liver and splanchnic tissues balance were calculated from plasma samples taken during the last $2 \mathrm{~h}$ of this infusion. Splanchnic tissues extracted $60 \%$ of infused labelled threonine, $88 \%$ of which was extracted by PDV so that threonine extraction by the liver was low. Both the liver and the pancreas can degrade threonine through the L-threonine 3-dehydrogenase pathway but not the intestine. Our data suggest that threonine catabolism through the L-threonine 3-dehydrogenase pathway was only a minor component of total threonine utilization in the splanchnic tissues.
\end{abstract}

Pigs: Threonine: Portal drained viscera: Liver

In pigs, threonine has been identified to be the first limiting amino acid for maintenance (Fuller et al. 1989), suggesting that threonine utilization for processes other than muscle protein synthesis and deposition is high. This also implies that threonine irreversible losses either through catabolism or through digestive endogenous losses are probably important. The high maintenance threonine requirement probably has its origin in specific metabolism of the splanchnic tissues composed by the gastrointestinal tract, i.e. small and large intestine, annexed organs such as spleen or pancreas and the liver. For example, Bertolo et al. (1998) have shown that threonine requirement of orally fed young piglets is twice as much as that of parenterally fed piglets. This statement was also confirmed by Stoll et al. (1998), who showed that about $60 \%$ of dietary threonine was extracted during its first pass across the portal drained viscera (PDV) in piglets fed a milk-based diet. These authors suggested that threonine catabolism was the main fate of threonine in the small intestine. However, in pigs, threonine is mainly degraded through the L-threonine 3-dehydrogenase (TDG, EC 1.1.1.103) pathway to give glycine and acetyl CoA in vivo and, until now, no experimental evidence has shown that the intestine could be involved in threonine catabolism in pigs. As for most of the essential amino acids, threonine catabolism occurs in the liver but also in the pancreas (Le Floc'h et al. 1997). Otherwise, intestinal threonine metabolism is strongly associated to mucin synthesis (Ball et al. 1999) and losses of threonine-rich protein synthesized and secreted in the gastrointestinal tract are often proposed to explain the high requirement for threonine.

These last years, we have developed a model of continuously infused animals in order to measure in vivo total threonine catabolism associated with measurement of in vitro tissue TDG activity (Ballèvre et al. 1991; Le Floc'h et al. 1996). However, until now, we never used this model to measure threonine catabolism separately in the PDV and in the liver. Such an approach requires the association of tracer infusion and measurement of the net appearance of labelled threonine both in the portal vein and in the hepatic vein. In the present work these techniques were used to measure threonine utilization by the splanchnic viscera in order to: (1) estimate the respective contributions of the PDV and the liver to total threonine metabolism; (2) determine if threonine catabolism could be or not a major contributor to threonine losses in the splanchnic area; (3) confirm or not the contribution of the PDV to this catabolism. In order to quantify the first pass utilization and catabolism of luminal threonine and because the splanchnic viscera receives amino acids from both the systemic circulation and the lumen, we decided to infuse labelled threonine either through

Abbreviations: BF, blood flow; DR, disposal rate; FC, fractional contribution; GC-C-IRMS, gas chromatography-combustion-isotope ratio mass spectrometry; Ht, haematocrit; HV, hepatic vein; Ks, fractional protein synthesis rate; MPE, mole per cent excess; PDV, portal drained viscera; PF, plasma blood flow; PV, portal vein; TDG, L-threonine 3-dehydrogenase.

* Corresponding author: Dr Nathalie Le Floc'h, fax +332234850 80, email Nathalie.Lefloch@ rennes.inra.fr 
the systemic intravenous route or through intraduodenal route. To do so, a first experiment was conducted to measure arterial threonine sequestration during a constant intravenous infusion of $\mathrm{L}-$ $\left[1-{ }^{13} \mathrm{C}\right]$ threonine. A second experiment was conducted to study threonine metabolism during intraduodenal threonine infusion. Arterial threonine sequestration rate as determined in the first experiment was used to calculate tracer first pass removal by the PDV and the liver. Threonine catabolism through the TDG pathway was also investigated in the splanchnic tissues through: (1) combining a constant infusion of $\left[{ }^{15} \mathrm{~N}\right]$ glycine in order to estimate in vivo threonine catabolism into glycine in the PDV and the liver; (2) measuring TDG activity in the different tissues composing the splanchnic area.

\section{Materials and methods}

\section{Animals and surgical procedures}

Experiment 1. The first experiment was conducted with four castrated Landrace $\times$ Large White pigs $(30.5 \pm 2 \mathrm{~kg}$ live weight at the infusion time) from the INRA herd. One week after their arrival in the experimental facilities, pigs were surgically prepared for chronic insertion of catheters and flow probes. After an overnight food deprivation, catheters were introduced under general anaesthesia (Halothane, Belamont, France) in the portal vein, in a hepatic vein and in the carotid artery for blood sampling, and in the jugular vein for tracer infusion. The portal catheter was inserted between the flow probe (see later) and the liver porta. Ultrasonic blood flow probes (Transonics, Ithaca, $\mathrm{NY}$, USA) of $14(14 \mathrm{SB})$ and $5(5 \mathrm{RB}) \mathrm{mm}$ internal diameter were placed around the portal vein and the hepatic artery, respectively, for continuous blood flow recording. The portal vein flow probe was placed on the common portal vein, upstream from the portal catheter, between the pancreatic vein and the portal vein catheter. At this level, measurements reflect the contribution of both the digestive tract and the pancreas. During the $2 \mathrm{~d}$ following surgery, a glucose solution was infused intravenously and post-operative analgesia was ensured by ketamine (Imalgène, Mérial Lyon, France). Antibiotic treatment was pursued for $5 \mathrm{~d}$ and a normal feed intake level was progressively reached in a few days. Catheters were aseptically rinsed every $2 \mathrm{~d}$ with heparinized saline. The experiment was conducted at least $10 \mathrm{~d}$ after surgery to ensure proper recovery of the pigs.

Experiment 2. Six female Pietrain $\times$ (Landrace $\times$ Large White) pigs were selected from the INRA herd at a mean weight of $25 \mathrm{~kg}$. One week after their arrival in the experimental facilities, pigs were surgically prepared for chronic insertion of catheters and flow probes as described for experiment 1 except that the jugular catheter was replaced by a duodenal catheter for tracer infusion. The average pig weight was $29.6 \pm 1.0 \mathrm{~kg}$ at the infusion time.

\section{Infusion protocol and blood sampling}

Two days before the infusion, pigs were fed hourly with an automatic feeder in order to ensure a near steady state for nutrient utilization necessary to simplify the study of threonine metabolism. The diet was a standard diet, the composition of which is described in Table 1. Composition of this diet was calculated to cover nutrient requirements according to Sève (1994). The amount of offered diet was adjusted to the metabolic weight $\left(100 \mathrm{~g} / \mathrm{kg}\right.$ body weight $\left.{ }^{075}\right)$ and delivered in twenty-four
Table 1. Composition of the standard diet

\begin{tabular}{lc}
\hline Ingredients & Amount in diet $(\mathrm{g} / \mathrm{kg})$ \\
\hline Wheat & $430 \cdot 12$ \\
Maize & 150 \\
Barley & 100 \\
Wheat bran & 50 \\
Soyabean meal & 203.07 \\
Vegetable oil & 8.90 \\
Molasses & 20 \\
Calcium carbonate & 14.08 \\
Phosphate & 9.91 \\
lodized salt & 4.5 \\
L-Lysine HCl* & 2.78 \\
Methionine hydroxy analogue & 0.44 \\
L-Threonine† & 0.45 \\
Trace mineral and vitamin premix $\ddagger$ & 5 \\
Mould inhibitor & 0.75 \\
\hline
\end{tabular}

*Contained $50 \%$ lysine.

† The amount of true digestible threonine provided by this diet is $5.88 \mathrm{~g} / \mathrm{kg}$ diet.

$\ddagger$ Provided the following amounts of trace elements and vitamins ( $\mathrm{mg} / \mathrm{kg}$ complete diet): $\mathrm{Fe}, 80 ; \mathrm{Cu}, 10 ; \mathrm{Mn}, 37$; $\mathrm{n}, 100$; Co, 0.1; I, 0.2; Se, 0.15; vitamin A, 5000; vitamin D3, 1000; vitamin E, 20; menadione, 1.99; thiamine, 1.96; riboflavin, 4; niacin, 15; panthotenic acid, 9.9; pyridoxine, 1; biotin, 0.2; folic acid, 1; cyanocobolamin, 0.02; choline, 600 .

equal meals. The mean threonine intakes were $8.0 \pm 1 \cdot 1 \mathrm{~g} / \mathrm{d}$ $(95.2 \pm 8.3 \mu \mathrm{mol} / \mathrm{kg}$ per $\mathrm{h})$ in experiment 1 and $8.2 \pm 1.2 \mathrm{~g} / \mathrm{d}$ $(96.4 \pm 7.9 \mu \mathrm{mol} / \mathrm{kg}$ per $\mathrm{h})$ in experiment 2 .

In experiment 1 , a solution of $\mathrm{L}-\left[1-{ }^{13} \mathrm{C}\right]$ threonine $(7 \mu \mathrm{mol} / \mathrm{kg}$ per h) was prepared in sterile saline and continuously infused through the jugular catheter for $10 \mathrm{~h}$. In experiment 2, $25.5 \mu \mathrm{mol} / \mathrm{kg}$ per $\mathrm{h}$ of $\mathrm{L}-\left[1-{ }^{13} \mathrm{C}\right]$ threonine and $1.45 \mu \mathrm{mol} / \mathrm{kg}$ per $\mathrm{h}$ of $\left[{ }^{15} \mathrm{~N}\right]$ glycine were continuously infused in the duodenum for $10 \mathrm{~h}$. The amount of infused threonine was doubled compared to experiment 1 in order to take into account the sequestration of the tracer in the splanchnic area. L- $\left[1-{ }^{13} \mathrm{C}\right]$ Threonine $(99.9 \%)$ was provided by Isotec France (Saint Quentin, France) and $\left[{ }^{15} \mathrm{~N}\right]$ glycine $(98 \%)$ was purchased from CIL (Andover, MA, USA).

The procedure described was followed during both experiments. Cables of the two flow probes were connected to a dual channel flow-meter (T206 Transonic, Ithaca, NY, USA) and blood flows in the portal vein and in the hepatic artery were continuously recorded during the infusion. During the last $2 \mathrm{~h}$ of infusion, $7 \mathrm{ml}$ blood were withdrawn from the portal vein, the hepatic vein and the carotid artery. Blood was centrifuged for plasma separation $\left(3100 \mathrm{~g}\right.$ for $20 \mathrm{~min}$ at $\left.4^{\circ} \mathrm{C}\right)$. At the end of infusion, pigs were killed with a lethal dose of pentobarbital in the carotid catheter. The positions of the catheters were checked in order to validate the accuracy of the surgical procedure.

In experiment 2, after laparotomy, the liver and the pancreas were quickly removed, rinsed, weighed and a piece of $10 \mathrm{~g}$ was frozen in liquid $\mathrm{N}_{2}$. The small intestine was rinsed with saline and the mucosa was removed by scraping with a microscope slide. Tissue samples were kept at $-80^{\circ} \mathrm{C}$ until analysis.

The research was conducted under the guidelines of the French Ministry of Agriculture and Fisheries for experiments on animals (authorization 7719).

\section{Analytical procedure}

For amino acid analysis, $700 \mu \mathrm{l}$ plasma were deproteinized in an equal volume of a solution of sulphosalicylic acid at $60 \mathrm{~g} / \mathrm{l}$. Plasma amino acid concentrations were determined by ion 
exchange liquid chromatography as described by Le Floc'h $e t$ al. (1999) using norvaline as an internal standard.

Plasma $(5 \mathrm{ml})$ and tissues $(2 \mathrm{~g})$ were deproteinized in TCA $(100 \mathrm{~g} / \mathrm{l})$ and prepared for amino acid extraction (Le Floc'h et al. 1997). Plasma and tissue $\left[{ }^{15} \mathrm{~N}\right]$ glycine, $\left[{ }^{13} \mathrm{C}\right]$ glycine and $\left[{ }^{13} \mathrm{C}\right]$ threonine were determined by gas chromatography-combustion-isotope ratio mass spectrometry (GC-C-IRMS; GC 8130 chromatograph interfaced with a VG Isochrom mass spectrometer, Fisons Instrument, UK) after derivatization with ethyl chloroformate as previously described (Le Floc'h et al. 1997). Results are expressed in mole per cent excess (MPE) after taking into account the 2- and 4-fold dilution of carbons from glycine and threonine, respectively, in the ethyl chloroformate derivative.

TDG specific activity in liver, pancreas and intestine was measured as the rate of in vitro aminoacetone formation according to Le Floc'h et al. (1994) except that protease inhibitors (Protease inhibitor cocktail tablets from Boehringer Mannheim, Germany) were added in the buffer used for tissue homogenization (one tablet for $100 \mathrm{ml}$ buffer).

\section{Calculations}

Threonine sequestration in the PDV and the liver. Blood flows were recorded for portal vein (PV) and hepatic artery. The blood flow of the hepatic vein (HV) was calculated as the sum of PV and hepatic artery blood flows. Because amino acid concentrations and enrichments were measured in the plasma, the recorded blood flows $(\mathrm{BF})$ had to be transformed in plasma blood flow (PF) after correction by the haematocrit $(\mathrm{Ht}, \%)$ values according to the following formula:

$$
\mathrm{PF}(1 / \mathrm{kg} \text { per } \mathrm{h})=\mathrm{BF} \times(100-\mathrm{Ht}) / 100
$$

Threonine, glycine and labelled threonine and glycine fluxes in a vessel were calculated as the product of amino acid ([AA]) or tracer concentrations ([AA] $\times \mathrm{E}$; where $\mathrm{E}$ is enrichment) and the plasma flow from the corresponding vessel. Amino acid concentrations were expressed in $\mu \mathrm{mol} / \mathrm{l}$ and enrichments in MPE.

Net amino acid balance ( $\mu \mathrm{mol} / \mathrm{kg}$ per $\mathrm{h}$ ) across the PDV and the liver were calculated as the difference between the efferent flux (or output) and the afferent flux (or input). This means that positive values will reflect a negative balance for the PDV and the liver. For example, PDV net balance was calculated as follows:

$$
\text { Net PDV } \mathrm{AA}_{\text {balance }}=\left([\mathrm{AA}]_{\mathrm{PV}}-[\mathrm{AA}]_{\mathrm{A}}\right) \times \mathrm{PF}_{\mathrm{PV}}
$$

where $[\mathrm{AA}]_{\mathrm{PV}}$ and $[\mathrm{AA}]_{\mathrm{A}}$ were the amino acid concentrations in the PV and the carotid artery, respectively. Liver balance was calculated as the difference between HV flux and the sum of PV and hepatic artery fluxes.

Tracer balance was calculated in the same way through multiplying amino acid concentration, by the threonine or glycine concentrations, by its enrichment in the corresponding vessel. For example, labelled threonine balance across the PDV was calculated as:

$$
\left([\mathrm{thr}]_{\mathrm{PV}} \times \mathrm{E}_{\mathrm{thrPV}}-[\mathrm{thr}]_{\mathrm{A}} \times \mathrm{E}_{\mathrm{thrA}}\right) \times \mathrm{PF}_{\mathrm{PV}}
$$

Liver tracer balance was calculated as the difference between $\mathrm{HV}$ flux $\left([\mathrm{thr}]_{\mathrm{HV}} \times \mathrm{E}_{\mathrm{thr}} \mathrm{HV} \times \mathrm{PF}_{\mathrm{HV}}\right)$ and the sum of $\mathrm{PV}$ and hepatic artery fluxes $\left([\mathrm{thr}]_{\mathrm{PV}} \times \mathrm{E}_{\text {thr } \mathrm{PV}} \times \mathrm{PF}_{\mathrm{PV}}+\left[\mathrm{thr}_{\mathrm{A}} \times \mathrm{E}_{\mathrm{thrA}} \times \mathrm{PF}_{\mathrm{A}}\right)\right.$.
During constant intravenous infusion of labelled $\left[1-{ }^{13} \mathrm{C}\right]$ threonine (experiment 1 ), $\left[{ }^{13} \mathrm{C}\right]$ threonine PDV balance corresponds to the PDV sequestration of $\left[1-{ }^{13} \mathrm{C}\right]$ threonine arriving from artery (see Appendix). Arterial tracer sequestration (Seq-art) by the PDV can be expressed in proportion to afferent flux, i.e. the flux of labelled threonine arriving from artery:

$$
\text { Proportion Seq-art, } \begin{aligned}
\% & =100 \times\left(\left[{ }^{13} \mathrm{C}\right] \text { threonine balance }\right) /(\text { afferent flux }) \\
& =100 \times(\text { Equation } 2) /\left(\left([\mathrm{thr}]_{\mathrm{A}} \times \mathrm{E}_{\mathrm{A}}\right) \times \mathrm{PF}_{\mathrm{PV}}\right)
\end{aligned}
$$

During intraduodenal infusion of $\left[1-{ }^{13} \mathrm{C}\right]$ threonine (experiment 2 ), we assumed that labelled threonine infused into the duodenum was completely absorbed. Consequently, the fraction of infused labelled threonine that did not appear in the efferent blood (PV or HV) was assumed to be extracted by the gastrointestinal tract to be either incorporated into protein or degraded.

According to the model presented in the Appendix, $\left[1-{ }^{13} \mathrm{C}\right]$ threonine PDV balance (Equation 2) corresponds to the difference between infusion rate and total tracer sequestration (first-pass removal of newly infused tracer and tracer recycled from artery). Thus, total tracer sequestration was calculated as:

Total tracer sequestration $=$ Intraduodenal infusion rate

$$
- \text { (Equation 2) }
$$

The same equation was used for $\left[{ }^{15} \mathrm{~N}\right]$ glycine intraduodenally infused.

PDV balance of $\left[1-{ }^{13} \mathrm{C}\right]$ threonine (Equation 2) also corresponds to the difference between the portal appearance of newly infused tracer (tracer infusion rate - tracer first-pass removal) and the sequestration of arterial $\left[1-{ }^{13} \mathrm{C}\right]$ threonine in the PDV (Seq-art). Consequently, tracer first-pass removal could be calculated as:

Tracer first-pass removal $=$ Intraduodenal infusion rate

$$
\begin{aligned}
& -(\text { Equation } 2)-\text { Seq-art } \\
& =(\text { Equation } 4)-\text { Seq-art }
\end{aligned}
$$

where Seq-art is determined from the proportion of arterial tracer sequestration by the PDV (Equation 3) calculated during the intravenous infusion of labelled threonine (experiment 1 ) as follows:

$$
\text { Seq }- \text { art }=(\text { Equation } 3) \times\left([\mathrm{thr}]_{\mathrm{A}} \times \mathrm{E}_{\mathrm{A}} \times \mathrm{PF}_{\mathrm{PV}}\right) / 100
$$

The proportion of labelled threonine extracted by the PDV during the first pass of the tracer was calculated as:

$$
\begin{aligned}
& \text { Proportion of tracer first-pass removal (\%) } \\
& \quad=100 \times(\text { Equation 5)/infusion rate }
\end{aligned}
$$

$\left[1-{ }^{13} \mathrm{C}\right]$ Threonine and $\left[{ }^{15} \mathrm{~N}\right]$ glycine liver balance (see Appendix) correspond to $\left[1-{ }^{13} \mathrm{C}\right]$ threonine and $\left[{ }^{15} \mathrm{~N}\right]$ glycine sequestration in the liver and can be expressed as the percentage of total input from the hepatic artery and the PV.

Finally, under steady-state conditions, threonine and glycine disposal rates (DR) in the PDV and the liver were calculated from $\left[1-{ }^{13} \mathrm{C}\right]$ threonine and $\left[{ }^{15} \mathrm{~N}\right]$ glycine total sequestration divided by threonine and glycine enrichments, respectively. 
Because enrichment in the mucosa was probably not representative of the whole PDV enrichment, DR was calculated from plasma PV enrichment. For threonine, DR corresponds to the sum of two metabolic fluxes: catabolism and incorporation into proteins.

Threonine catabolism. In this section, we detail the formulas used to calculate irreversible threonine degradation into glycine in the PDV and the liver. The fractional contribution of threonine to glycine flux $\left(\mathrm{FC}_{\mathrm{thr} \rightarrow \mathrm{gly}}\right)$ was calculated as the ratio of glycine to threonine enrichment during the intraduodenal infusion of $\left[1-{ }^{13} \mathrm{C}\right]$ threonine. This value, $\mathrm{FC}_{\mathrm{thr} \rightarrow \mathrm{gly}}$, gives the percentage of glycine flux that comes from threonine degradation by the TDG pathway. The rate of threonine degradation in the PDV and the liver through the TDG pathway was calculated by multiplying the fractional contribution of threonine to glycine flux by glycine DR. Glycine DR was calculated during the constant $\left[{ }^{15} \mathrm{~N}\right]$ glycine infusion as described earlier. For the PDV, all calculations were made with plasma values of enrichment measured in the PV assuming that they reflected the average enrichments for the whole PDV. For the liver, we used liver enrichment values.

\section{Statistical analysis}

Data were submitted to variance analysis according to the general linear model procedure of SAS (SAS Institute Inc., Cary, NC, USA). All presented data correspond to mean values for samples taken during the last $2 \mathrm{~h}$ of continuous infusion except for the blood flow, which was continuously recorded during the whole period of infusion. Balances were tested against zero by $t$ test.

\section{Results}

All the animals were in good health and had normal growth rates for pigs submitted to feed rationing and to such a surgical preparation. They consumed the totality of the allocated feed during the period of continuous feeding. Previous experiments showed that glycine enrichments reached plateau values after $8 \mathrm{~h}$ of continuous labelled threonine intravenous infusion (Le Floc'h et al. 1995). The plateau for threonine enrichments was obtained earlier around the fourth hour of infusion. Therefore, we limited the period of blood sampling to the last $2 \mathrm{~h}$ of infusion when threonine and glycine enrichments were nearly constant. Plateau values for threonine and glycine enrichments during the continuous infusion of $\left[1-{ }^{13} \mathrm{C}\right]$ threonine in the duodenum are given in Fig. 1.

During the infusion period portal plasma flow did not show more than $15 \%$ of variation. Mean values for plasma flow were similar in both experiments $(1.81$ v. $1.641 / \mathrm{kg}$ per $\mathrm{h}$ for portal plasma flow in experiments 1 and 2, respectively). The values of plasma flow in hepatic artery were 0.3 and $0.11 / \mathrm{kg}$ per $\mathrm{h}$ in experiments 1 and 2, respectively. Threonine and glycine concentrations measured in the different vessels were similar in both experiments (Tables 2 and 4), attesting that pigs were in a comparable nutritional state in spite of the difference between the threonine infusion rate in the two experiments $(7 v .25 .5 \mu \mathrm{mol} /$ $\mathrm{kg}$ per $\mathrm{h})$ and the induced difference in net portal balance $(28.8$ v. $45.2 \mu \mathrm{mol} / \mathrm{kg}$ per h). Consequently, we assumed that the rate of arterial threonine sequestration by the PDV and the splanchnic area calculated from the data of experiment 1 could be used for estimating first-pass extraction of intraduodenally infused
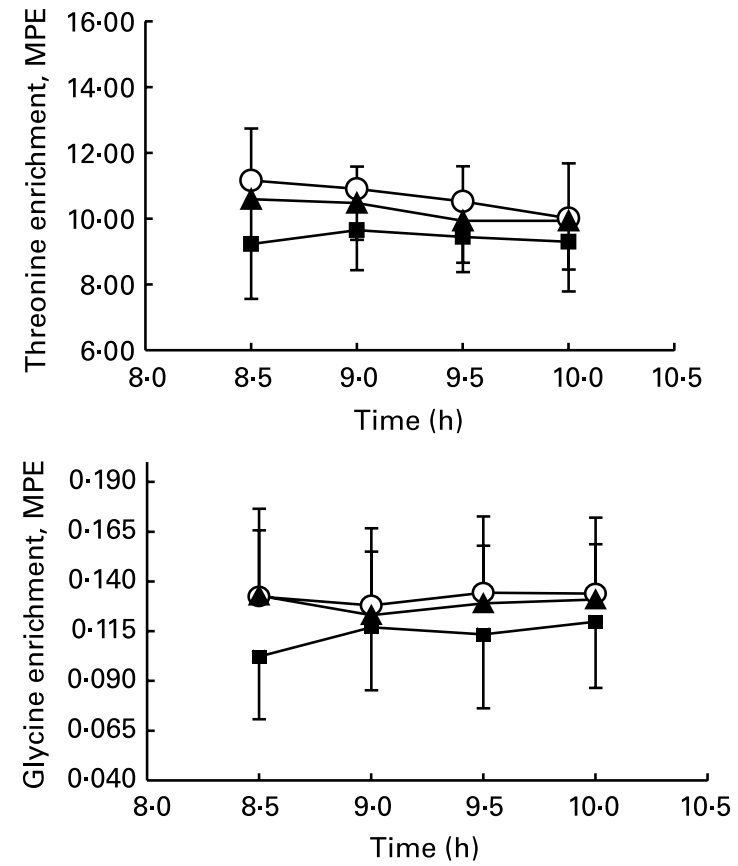

Fig. 1. Plateau values of $\left[1-{ }^{13} \mathrm{C}\right]$ threonine and $\left[{ }^{13} \mathrm{C}\right]$ glycine enrichment in artery $(\boldsymbol{\square})$, portal vein $(O)$ and hepatic vein $(\boldsymbol{\Lambda})$ measured during the last $2 \mathrm{~h}$ of continuous infusion of $25.5 \mu \mathrm{mol} / \mathrm{kg}$ per $\mathrm{h}$ of $\mathrm{L}-\left[1-{ }^{13} \mathrm{C}\right]$ threonine in the duodenum. Values are means, with their standard errors depicted by vertical bars, for six pigs. Enrichments are expressed in mole per cent excess (MPE).

threonine in experiment 2. Arterial $\left[1-{ }^{13} \mathrm{C}\right]$ threonine sequestration calculated during intravenous $\left[1-{ }^{13} \mathrm{C}\right]$ threonine infusion corresponds to 14.3 and $18.8 \%$ of arterial input for PDV and total splanchnic tissues, respectively (Table 3 ).

Threonine and glycine enrichments in the different vessels and tissues, measured after $10 \mathrm{~h}$ of $\left[1{ }^{13} \mathrm{C}\right]$ threonine continuous infusion in the duodenum, are presented in Table 4. The enrichment of free $\left[1-{ }^{13} \mathrm{C}\right]$ threonine in the pancreas was very close to values found in plasma but much higher than those measured in the free pools of the small intestine mucosa and the liver. The enrichment of threonine bound to protein was much lower than in the tissue free pool. However, protein of the pancreas and small intestine mucosa were significantly more enriched than liver protein. During $\mathrm{L}-\left[1-{ }^{13} \mathrm{C}\right]$ threonine infusion, glycine ${ }^{13} \mathrm{C}$ enrichment was significantly higher in the plasma than in the tissue free pool except in the pancreas in which the enrichment was 10-fold higher than in the plasma.

After subtracting the arterial labelled threonine sequestration from total labelled threonine sequestration we calculated that $52.2 \%$ of threonine infused into the duodenum was extracted by the PDV (Table 5). These tissues preferentially used threonine from the intestinal lumen since $75 \%$ of threonine removed by the PDV came from the infusion. By comparison threonine sequestration in the liver was much lower $(5.3 \%$ of total liver input corresponding to the sum of tracer arrival from the hepatic artery and the PV). The balance of $\left[1-{ }^{13} \mathrm{C}\right]$ glycine across the PDV that was measured during constant $\left[1-{ }^{13} \mathrm{C}\right]$ threonine infusion was low but significantly positive whereas liver $\left[1-{ }^{13} \mathrm{C}\right]$ glycine balance was not significantly different from zero.

Threonine disposal rate $\left(\mathrm{DR}_{\text {thr }}\right)$ values were 174.8 and $40 \cdot 2 \mu \mathrm{mol} / \mathrm{kg}$ per $\mathrm{h}$ in the PDV and the liver, respectively 
Table 2. Plasma threonine concentrations and enrichments during the continuous infusion of L-[1- $\left.{ }^{13} \mathrm{C}\right]$ threonine in the jugular vein (experiment 1$)^{\star}$ (Mean values with their standard errors for four pigs)

\begin{tabular}{|c|c|c|c|c|c|c|c|c|c|c|}
\hline \multirow[b]{2}{*}{ Vessels } & \multicolumn{2}{|c|}{$\begin{array}{l}\text { Plasma threonine } \\
\text { concentration } \\
(\mu \mathrm{mol} / \mathrm{l})\end{array}$} & \multicolumn{2}{|c|}{$\begin{array}{l}\text { Plasma flow } \\
\text { (l/kg per h) }\end{array}$} & \multicolumn{2}{|c|}{$\begin{array}{l}\text { Plasma threonine } \\
\text { enrichment (MPE) }\end{array}$} & \multicolumn{2}{|c|}{$\begin{array}{l}\text { Threonine flux } \\
\text { ( } \mu \mathrm{mol} / \mathrm{kg} \text { per } \mathrm{h})\end{array}$} & \multicolumn{2}{|c|}{$\begin{array}{l}{\left[1-{ }^{13} \mathrm{C}\right] \text { Threonine }} \\
\text { flux }(\mu \mathrm{mol} / \mathrm{kg} \text { per } \mathrm{h})\end{array}$} \\
\hline & Mean & SE & Mean & SE & Mean & SE & Mean & SE & Mean & SE \\
\hline Artery & 191.8 & $9 \cdot 4$ & 0.3 & 0.05 & 3.09 & 0.21 & $57 \cdot 0$ & 9.4 & 1.84 & 0.17 \\
\hline Portal vein & 207.4 & $11 \cdot 8$ & $1 \cdot 8$ & 0.28 & $2 \cdot 45$ & 0.12 & $327 \cdot 7$ & $64 \cdot 3$ & 8.93 & $1 \cdot 21$ \\
\hline Hepatic vein & $195 \cdot 3$ & 13.2 & $2 \cdot 1 \dagger$ & 0.33 & $2 \cdot 48$ & 0.23 & $367 \cdot 4$ & 76.5 & 9.93 & 1.04 \\
\hline
\end{tabular}

MPE, mole percent excess.

${ }^{*} \mathrm{~L}-\left[1-{ }^{13} \mathrm{C}\right]$ Threonine infusion rate was $7 \mu \mathrm{mol} / \mathrm{kg}$ per $\mathrm{h}$ and average threonine intake was $8.0 \mathrm{~g} / \mathrm{d}(95.2 \mu \mathrm{mol} / \mathrm{kg} \mathrm{per} \mathrm{h})$.

† Hepatic vein plasma flow was calculated as the sum of portal vein and hepatic vein plasma flows.

(Table 6). Threonine fractional contribution to glycine flux $\left(\mathrm{FC}_{\mathrm{thr} \rightarrow \mathrm{gly}}\right)$ was twice as much in the liver than in the PV. By comparison, the values of $\mathrm{FC}_{\mathrm{thr} \rightarrow \mathrm{gly}}$ calculated from enrichments measured in the mucosa and the pancreas were 1.2 and $14.7 \%$,

Table 3. Portal drained viscera and splanchnic tissue threonine balance calculated during the continuous infusion of $L-\left[1-{ }^{13} \mathrm{C}\right]$ threonine in the jugular vein (experiment 1$)^{*}$

(Mean values with their standard errors for four pigs)

\begin{tabular}{|c|c|c|c|c|c|c|}
\hline \multirow[b]{4}{*}{ Tissues } & \multicolumn{6}{|c|}{ Threonine balance } \\
\hline & \multirow{2}{*}{\multicolumn{2}{|c|}{$\begin{array}{c}\text { Net balance } \dagger \\
(\mu \mathrm{mol} / \mathrm{kg} \\
\text { per } \mathrm{h})\end{array}$}} & \multicolumn{4}{|c|}{ Tracer balance $\ddagger$} \\
\hline & & & \multicolumn{2}{|c|}{$\begin{array}{c}(\mu \mathrm{mol} / \mathrm{kg} \\
\text { per } \mathrm{h})\end{array}$} & \multicolumn{2}{|c|}{$\begin{array}{c}\text { (\% of arteria } \\
\text { input) }\end{array}$} \\
\hline & Mean & $\mathrm{SE}$ & Mean & SE & Mean & SE \\
\hline Portal drained viscera & $28 \cdot 8$ & $6 \cdot 3$ & -1.51 & 0.19 & $14 \cdot 3$ & $2 \cdot 4$ \\
\hline Splanchnic tissues & 8.9 & $1 \cdot 1$ & 2.45 & 0.41 & $18 \cdot 8$ & 2.4 \\
\hline
\end{tabular}

${ }^{*} \mathrm{~L}-\left[1-{ }^{13} \mathrm{C}\right]$ Threonine infusion rate was $7 \mu \mathrm{mol} / \mathrm{kg}$ per $\mathrm{h}$ and average threonine intake was $8.0 \mathrm{~g} / \mathrm{d}(95.2 \mu \mathrm{mol} / \mathrm{kg}$ per $\mathrm{h})$.

† Net balance is calculated as the difference between total threonine output and total threonine input (calculations are described in p. 448).

$\ddagger$ Tracer balance is calculated as the difference between $\left[{ }^{13} \mathrm{C}\right]$ threonine output and $\left[{ }^{13} \mathrm{C}\right]$ threonine input (calculations are described in p. 448). respectively. The rates of threonine catabolism into glycine estimated in the PDV and the liver were not significantly different from each other $(2.74$ v. $3.50 \mu \mathrm{mol} / \mathrm{kg}$ per h, respectively). As expected, TDG activity was found in the liver and the pancreas but was not detected in the mucosa of the small intestine in spite of the addition of antiproteolytic enzymes in the homogenate buffer (Table 6). Liver TDG activity expressed by gram of tissue was significantly lower than that measured in the pancreas $(1.46 \mathrm{v}$. $5.62 \mu \mathrm{mol} / \mathrm{min}$ ). However the liver total activity, expressed in $\mu \mathrm{mol} / \mathrm{h}$ per $\mathrm{kg}$ body weight as presented in Table 6 , was five times the total activity measured in the pancreas.

\section{Discussion}

$\mathrm{PV}$ is the main route for most digestion products after their absorption and their transfer across the digestive tract. The PV balance technique has been used extensively to measure the appearance of dietary amino acids in the blood flow and thus mainly used as an amino acid absorption indicator when expressed as a proportion of dietary intake (Rérat et al. 1988; Simoes-Nunes et al. 1991; Stoll et al. 1998) and more rarely to measure amino acid disappearance from the lumen (DarcyVrillon et al. 1991). Generally, this comparison shows that

Table 4. Plateau values for threonine and glycine enrichments and concentrations in plasma and tissue free and protein pools of pigs during the intraduodenal infusion of L-[1- $\left.{ }^{13} \mathrm{C}\right]$ threonine (experiment 2$)^{*}$

(Mean values with their standard errors for six pigs)

\begin{tabular}{|c|c|c|c|c|c|c|c|c|c|c|}
\hline \multirow{2}{*}{ Site } & \multicolumn{4}{|c|}{ Concentrations $(\mu \mathrm{mol} / \mathrm{l})$} & \multicolumn{6}{|c|}{ Enrichments (MPE) } \\
\hline & \multicolumn{2}{|c|}{ Threonine } & \multicolumn{2}{|c|}{ Glycine } & \multicolumn{2}{|c|}{$\left[{ }^{13} \mathrm{C}\right]$ Threonine } & \multicolumn{2}{|c|}{$\left[{ }^{13} \mathrm{C}\right]$ Glycine } & \multicolumn{2}{|c|}{$\left[{ }^{15} \mathrm{~N}\right]$ Glycine } \\
\hline \multicolumn{11}{|l|}{ Plasma } \\
\hline Carotid artery & $194 \cdot 2$ & $13 \cdot 6$ & $478 \cdot 4$ & 48.5 & 9.44 & 0.13 & $0 \cdot 118$ & 0.002 & $0 \cdot 19^{b}$ & 0.07 \\
\hline Portal vein & $219 \cdot 5$ & 1.5 & $520 \cdot 3$ & $36 \cdot 2$ & $10 \cdot 86$ & 0.24 & 0.124 & 0.001 & $0.07^{a}$ & 0.07 \\
\hline \multicolumn{11}{|l|}{ Tissue free } \\
\hline Mucosa & & & & & $4 \cdot 64^{\mathrm{a}}$ & 0.002 & $0.091^{a}$ & 0.002 & $0 \cdot 14$ & 0.06 \\
\hline Liver & & & & & $7 \cdot 25^{\mathrm{b}}$ & 0.002 & $0.093^{a}$ & 0.002 & 0.11 & 0.01 \\
\hline Pancreas & & & & & $9 \cdot 48^{\mathrm{C}}$ & 0.002 & $1 \cdot 32^{b}$ & 0.002 & 0.12 & 0.01 \\
\hline \multicolumn{11}{|l|}{ Tissue protein } \\
\hline Mucosa & & & & & $1.82^{\mathrm{ab}}$ & 0.002 & $0.01^{a}$ & 0.002 & 0.066 & 0.002 \\
\hline Liver & & & & & $0.72^{\mathrm{a}}$ & 0.002 & $0.003^{a}$ & 0.002 & 0.012 & 0.002 \\
\hline Pancreas & & & & & $2 \cdot 44^{\mathrm{b}}$ & 0.002 & $0.41^{\mathrm{b}}$ & 0.002 & 0.032 & 0.002 \\
\hline
\end{tabular}

MPE, mole percent excess.

${ }^{*}$ For plasma, plateau values of concentrations and enrichments were calculated from samples taken during the last $2 \mathrm{~h}$ of infusion (four blood samples per animal).

${ }_{a, b, c}$ Mean values with unlike superscript letters in the same column and in the same compartment (plasma, tissue-free or tissue protein) were significantly different $(P<0.05)$. 
much less than $100 \%$ of ingested amino acid appears in the PV except for some non-essential amino acids, such as alanine (Rérat et al. 1992; Le Floc'h et al. 1999) that is synthesized from glutamine and glutamate in the enterocyte. Differences between amino acid appearance in the PV and amino acid absorbed from the diet reflect amino acid metabolism associated to amino acid extraction by the viscera (utilization for protein synthesis or catabolism) or production (amino acid release from protein breakdown and de novo synthesis for non-essential amino acids). However, an accurate study of amino acid metabolism in tissues will require labelled amino acid infusion to calculate the flux of amino acid sequestered and then metabolized in the viscera. Because the liver is assumed to be the main tissue involved in most essential amino acid catabolism, except the branched chain amino acid, it is possible to estimate the availability of amino acid for peripheral tissues, especially for muscle protein accretion, through integrating the $\mathrm{HV}$ in the splanchnic balance measurement (Rérat et al. 1992; Deutz et al. 1996).

Threonine disappearance across the portal drained viscera and the liver

A significant contribution of the gastrointestinal tissues to essential amino acid metabolism is now accepted. For example, studies performed in pigs (Stoll et al. 1998) and in dogs (Yu et al. 1990) suggested that the PDV can utilize on average half of the essential amino acids provided by the diet. Our data confirmed this statement for threonine, showing that almost one-third of threonine arriving (newly infused and recycled from artery) in the PDV and in the whole splanchnic tissues did not appear in the PV and thus were assumed to be extracted. An accurate estimation of dietary threonine removal by the PDV requires a correction of total tracer balance by arterial extraction of re-circulating tracer from artery (Yu et al. 2000). This calculation provides a precise estimation of the availability of dietary threonine for all tissues, including the PDV, after absorption. The PDV are made of a heterogeneous group of tissues, among them the small intestine tissue that can use amino acids from two sources: lumen and artery. The contribution of these two sources is likely to change according to the nutritional status of the animal and the amino acids (MacRae et al. 1997b; Stoll et al. 1997). Data obtained in sheep (MacRae et al. 1997a) showed that the gastrointestinal tract extracts from $6.3 \%$, for histidine, to $12.0 \%$, for threonine, and $12.6 \%$, for leucine, of the arterial supply. In pigs intravenously infused with labelled threonine, we estimated that $14.3 \%$ of arterial threonine was extracted by the PDV. This is a little higher than values reported by Stoll et al. (1999) for phenylalanine, the concentration of which in mucosal protein is much lower than for threonine. Therefore, it appears that in continuously fed pigs, the PDV preferentially used luminal threonine since more than $70 \%$ of total threonine removed by these tissues came from a luminal source. Finally, in the first pass, we showed that the PDV extracted more than $50 \%$ of newly infused threonine. This result agrees with other data (Stoll et al. 1998; Ball, 2002) suggesting that the PDV contribute to whole-body threonine metabolism.

Compared to the whole PDV, liver utilization of threonine was much lower, confirming the observations of Rérat et al. (1992) showing that dietary threonine seems to be poorly taken up into the liver compared to the other essential amino acids, except the branched chain amino acids. Transport into the hepatocytes would be the limiting step for threonine utilization in the liver 
Table 6. Threonine and glycine disposal rate $(\mathrm{DR})$, threonine degradation into glycine $\left(\mathrm{OX}_{\mathrm{thr} \rightarrow \mathrm{gly}}\right)$ fractional contribution of threonine to glycine flux $\left(\mathrm{FC} \mathrm{T}_{\mathrm{Thr} \rightarrow \mathrm{Gly}}\right)$ and L-threonine 3-dehydrogenase (TDG) activity in the portal drained viscera (PDV) and the liver in six pigs infused with L-[1- $\left.{ }^{13} \mathrm{C}\right]$ threonine and $\left[{ }^{15} \mathrm{~N}\right] \mathrm{glycine}$ in the duodenum*

(Mean values with their standard errors for six pigs)

\begin{tabular}{|c|c|c|c|c|c|c|c|c|c|c|}
\hline \multirow{2}{*}{ Tissue } & \multicolumn{6}{|c|}{ Flux $(\mu \mathrm{mol} / \mathrm{kg}$ per $\mathrm{h})$} & & & \multirow{2}{*}{\multicolumn{2}{|c|}{$\begin{array}{c}\text { TDG activity } \\
(\mu \mathrm{mol} / \mathrm{kg} \text { body wt } \\
\text { per } \mathrm{h}) \dagger\end{array}$}} \\
\hline & \multicolumn{2}{|c|}{$\mathrm{DR}_{\mathrm{Thr}}$} & \multicolumn{2}{|c|}{$\mathrm{DR}_{\text {Gly }}$} & \multicolumn{2}{|c|}{$\mathrm{Ox}_{\mathrm{Thr} \rightarrow \mathrm{Gly}}$} & \multicolumn{2}{|c|}{$\mathrm{FC}_{\text {Thr } \rightarrow \text { Gly }}(\%)$} & & \\
\hline PDV & $174 \cdot 8$ & $46 \cdot 1$ & $437 \cdot 8$ & 110 & $2 \cdot 74$ & 0.59 & 0.64 & $0 \cdot 16$ & $537 \ddagger$ & 233 \\
\hline Liver & $40 \cdot 2$ & $26 \cdot 5$ & $220 \cdot 6$ & $73 \cdot 3$ & 3.50 & $2 \cdot 33$ & 1.34 & 0.88 & 2496 & 944 \\
\hline
\end{tabular}

${ }^{*}$ All the calculations are described and commented on in the section 'Calculations' of the Materials and methods. The value of hepatic artery plasma flow is $0.1 \pm 0.02 \mathrm{l} / \mathrm{kg}$ per $\mathrm{h}$. TTDG activity is expressed as the rate of in vitro aminoacetone formation.

$\ddagger$ No activity was detected in the intestine. PDV activity corresponds to the activity measured in the pancreas.

and could contribute to spare threonine for the peripheral tissues in preventing catabolism by the enzymes located in the liver (Le Floc'h et al. 1996).

Therefore, our data imply that among splanchnic tissues, the PDV rather than the liver are involved in threonine metabolism as has already been concluded for leucine (Yu et al. 1990) and phenylalanine (Stoll et al. 1997). The respective contributions of the PDV and the liver to threonine metabolism can be explained by their physiological roles: the tissues of the gastrointestinal tract require threonine to sustain their own functions and growth, whereas the liver is mainly involved in the catabolism of excess amino acid. From this point of view, the low value of liver threonine sequestration reported in the present study was rather surprising in view of the large amount of threonine provided by the infusion ( $20 \%$ of dietary threonine). However, continuous feeding and infusion may have prevented threonine from catabolism in decreasing the postprandial concentration peak in the portal blood. Otherwise this result agrees with observations made by Yamashita \& Ashida (1971) in rats and Darling et al. (2000) in human subjects who showed that plasma threonine response to dietary threonine supply was not very well regulated. They hypothesized that threonine catabolism may fail to prevent threonine accumulation in the body pool following an excess of dietary threonine.

\section{Threonine metabolism in the portal drained viscera and in the liver}

The present experiment clearly showed that a low proportion of infused $\left[1-{ }^{13} \mathrm{C}\right]$ threonine appeared in the PV and the HV. However, the fate of extracted threonine in the splanchnic area still remains controversial. From measured values of threonine extraction by the PDV and after having estimated that a low proportion of threonine was incorporated into protein of the intestinal mucosa, Stoll et al. (1998) concluded that threonine catabolism was the main pathway for threonine utilization in the PDV tissues, particularly in the small intestine. In fed pigs, threonine is mainly degraded through the TDG pathway to form glycine and acetyl CoA whereas TDG is a minor pathway in adult man (Darling et al. 2000). Previous estimations showed that about $1 \mathrm{~g}$ threonine/d was degraded through the TDG pathway in $30 \mathrm{~kg}$ pigs fed a well-balanced diet (Le Floc'h et al. 1995). Threonine can also be degraded through the TDH pathway to form 2-ketobutyric acid. In pigs this last enzyme contributes to less than $20 \%$ of in vivo threonine catabolism (Ballèvre et al. 1990, 1991) and it is unlikely that threonine disappearance across the intestine occurs through this secondary metabolic pathway. Threonine catabolism through the TDG pathway is supposed to occur mainly in the liver but a significant contribution of the pancreas has already been demonstrated in pigs (Le Floc'h et al. 1997) and chickens (Davis \& Austic, 1982), whereas no enzyme activity was detected in the intestine of the first species. As proposed by $\mathrm{Wu}$ (1998), the lack of enzyme activity detected in an intestine homogenate could be the consequence of the high protease activity in the intestinal mucosa. In the present experiment, we added protease inhibitors when preparing tissue extract. This addition did not seem to induce any positive or negative effect on the measured enzyme activity in the pancreas and the liver, and, again, activity was found neither in the intestinal tissue (small and large intestine) nor in the associated lymph nodes. As a consequence, we can conclude that in pig the intestine does not contain active TDG despite being able to calculate a significant flux of threonine degradation into glycine and a significant net appearance of $\left[1-{ }^{13} \mathrm{C}\right]$ glycine in the PV. Therefore, in the present experiment, the net appearance of labelled glycine in the PV should be ascribed to pancreatic enzyme activity since the pancreas is drained by the PV where blood was withdrawn for analysis. It is important to underline that $\left[1-{ }^{13} \mathrm{C}\right]$ glycine balance measured during the infusion of $\left[1{ }^{13} \mathrm{C}\right]$ threonine probably underestimates glycine production since newly synthesized glycine is likely to be metabolized in the tissue where threonine is degraded into glycine. This point of the discussion also allows the underlining of the limit of the comparison between in vitro (enzyme activity) and in vivo estimation of threonine catabolism through the TDG pathway. Indeed the relative difference in the flux of threonine catabolism to glycine between the PDV and the liver $30 \%$ higher rate in liver) is not proportionate to the difference in enzyme activity measurements (a 5-fold higher rate in liver). In vivo, catabolism depends on the amount of active enzyme but also on the availability of threonine for the enzyme itself. This means that threonine plasma concentrations as well as threonine transport in the tissue are probably major factors controlling the flux of threonine catabolism through the TDG pathway as measured in vivo.

From data presented in Table 6, we calculated that 1.6 and $7.7 \%$ of threonine extracted and metabolized in the PDV and the liver, respectively, were degraded through the TDG pathway. This means that, in a $30 \mathrm{~kg}$ pig, the splanchnic tissues metabolize about $20 \mathrm{~g}$ threonine/d - depending on the precursor pool 
enrichment used for calculation - but only $0.5 \mathrm{~g}$ threonine/d would be irreversibly lost through conversion into glycine. Thus, we conclude that the high rate of threonine sequestration in the PDV cannot be mainly explained by threonine catabolism through the usual metabolic pathway. Moreover, our estimation of threonine irreversible loss through catabolism seems very low in regard to the known value of threonine efficiency for protein deposition in pigs (Sawadogo, 1997). Therefore, other hypotheses must be considered to explain total threonine irreversible losses.

Assuming that infused labelled threonine was totally absorbed, the difference between threonine DR and threonine degradation into glycine should represent an estimation of the rate of threonine incorporation into protein. This flux corresponds to a unidirectional flux of threonine from free pool to protein and it does not correspond to the proportion of threonine finally retained in the PDV because of the high turnover rate occurring in the digestive tissues. On this basis, we calculated that 14.5 and $3.7 \mathrm{~g}$ threonine/d would be incorporated into protein of the PDV and the liver, respectively. For the PDV, this represents almost twice the amount of threonine provided by the diet. We measured the level of threonine enrichment in protein of the mucosa, the pancreas and the liver. The enrichments of threonine bound to protein were quite high in the pancreas and the mucosa ( 2.44 and $1.82 \mathrm{MPE})$ compared to that of the liver (0.72 MPE), suggesting that threonine incorporation in the protein of the mucosa and the pancreas would be very important. It is now well known that threonine is an important component of the gastrointestinal mucus (Marshall \& Allen, 1978; Mantle \& Allen, 1981), especially of mucin proteins. In pigs, Myrie et al. (2003) suggested that an increase in mucin production reduces body threonine retention. Moreover, an adequate level of dietary threonine was shown to be crucial for mucin production and maintenance of gut function and integrity in piglets (Ball et al. 1999; Ball 2002). Another consequence of the high labelling of protein is that a significant contribution of tracer recycling to the portal blood labelling may have occurred and probably led to an underestimation of tracer sequestration and thus of non-oxidative threonine DR in the PDV. However, it appears that no significant threonine recycling occurred from protein of the mucosa in the PV (van der Schoor et al. 2002), suggesting that these proteins could be very resistant to digestion. Alternatively, recycled threonine might be immediately reincorporated into mucosa protein instead of being absorbed or lost in the lumen.

The absolute amount of synthesized proteins in the splanchnic tissues we estimated from tracer sequestration is very high. Indeed, assuming an average threonine content of $3.9 \mathrm{~g} / 100 \mathrm{~g}$ for visceral proteins (Bikker et al. 1994), we calculated (Table 7) that 372 and $93 \mathrm{~g}$ protein would be synthesized per $\mathrm{d}$ by the PDV and the liver (12.6 g and $3.1 \mathrm{~g}$ per $\mathrm{kg}$ body weight of protein synthesized per $\mathrm{d}$ ). According to previous measurements made in pig and using the flooding dose technique (Sève et al. 1993), the fractional protein synthesis rate (Ks) would be about $100 \%$ for the intestine and $50 \%$ for the liver. The estimations of the amount of synthesized protein per $\mathrm{d}$ from these Ks values require the knowledge of tissue protein content. Assuming a protein content of $150 \mathrm{mg} / \mathrm{g}$ tissue, this means that the liver would synthesize about $2 \cdot 2 \mathrm{~g} /$ body weight of protein per $\mathrm{d}$, a value close to the value of $3.1 \mathrm{~g}$ we estimated with the balance technique. For the PDV, the discrepancy between the two estimations is much more important
Table 7. Estimation of protein synthesis in the portal drained viscera (PDV) and the liver of pigs infused with $L-\left[1-{ }^{13} \mathrm{C}\right]$ threonine and $\left[{ }^{15} \mathrm{~N}\right]$ glycine in the duodenum

(Mean values with their standard errors for six pigs)

\begin{tabular}{|c|c|c|c|c|c|c|}
\hline \multirow[b]{3}{*}{ Tissue } & \multicolumn{4}{|c|}{ Threonine incorporated in the proteins ${ }^{*}$} & \multirow{2}{*}{\multicolumn{2}{|c|}{$\begin{array}{c}\text { Protein } \\
\text { synthesizedt } \\
\text { (g/d per kg } \\
\text { body wt) }\end{array}$}} \\
\hline & \multicolumn{2}{|c|}{$(\mu \mathrm{mol} / \mathrm{kg}$ per h) } & \multicolumn{2}{|c|}{$(g / d)$} & & \\
\hline & Mean & SE & Mean & SE & Mean & SE \\
\hline PDV & $172 \cdot 0$ & $46 \cdot 0$ & $14 \cdot 5$ & 3.4 & $12 \cdot 6$ & 3.4 \\
\hline Liver & 41.9 & $25 \cdot 6$ & 3.6 & $2 \cdot 2$ & 3.1 & 1.8 \\
\hline
\end{tabular}

${ }^{*}$ Calculated as the difference between threonine disposal rate and threonine catabolism through the TDG pathway.

† Calculated from the amount of threonine incorporated in the proteins and assuming a threonine content of $3.9 \mathrm{~g} / 100 \mathrm{~g}$ protein (from Bikker et al. 1994).

in absolute value $(12.6 v .5-9 \mathrm{~g} / \mathrm{kg}$ body weight per d depending on the site of intestine used for calculation or the age of the pig). The overestimation of non-oxidative threonine DR can be partly explained because we probably underestimated threonine catabolism in considering only the TDG pathway. However, we cannot exclude that threonine sequestration, and thus threonine DR in the PDV, had been overestimated by balance techniques rather than underestimated as suggested earlier. In particular, we can question the complete absorption and total availability of the infused tracer. For example, the impact of gut microflora - in degrading rather than providing luminal threonine - on the availability of this amino acid for the pig leads to new questioning and produces interesting areas of research for the future.

In conclusion, our results are consistent with previous experiments that showed an important disappearance of threonine across the splanchnic tissues, especially the PDV, whereas the liver seems to be less involved in threonine metabolism. Threonine is probably not degraded by the intestine, at least by known enzymes. Our results suggest that most of the maintenance requirement for threonine could be explained by the incorporation of threonine in the protein of the digestive tract and consequently through digestive losses. Finally, the contribution of threonine catabolism to obligatory threonine losses appears to be low.

\section{Acknowledgements}

This paper was presented in part during the 1st Symposium on Energy and Protein Metabolism and Nutrition, Rostock-Warnemünde, Germany, 13-18 September 2003. The authors acknowledge Y. Colléaux for amino acid analysis, P. Ganier for GC-C-MS measurements, Nadine Mézière for her help during infusion, Y. Lebreton for surgery and F. Legouevec for animal care.

\section{References}

Ball RO (2002) Definition of amino acid requirement in pigs: partitioning between gut and muscle. In Proceedings of Canadian Society of Animal Science Symposium, p. 17-26 [H Lapierre and DR Ouelet, editors]. Quebec: Canadian Society of Animal Science.

Ball RO, Law G, Bertolo RFP \& Pencharz PB (1999) Adequate oral threonine is critical for mucin production and mucosal growth by neonatal piglet gut. In VIIIth International Symposium on Protein Metabolism 
and Nutrition, p. 31 [GE Lobley, A White and JC MacRae, editors]. Wageningen: Wageningen Pers.

Ballèvre O, Cadenhead A, Calder AG, Ree WD, Lobley GE, Fuller MF \& Garlick PJ (1990) Quantitative partition of threonine oxidation in pigs: effect of dietary threonine. Am J Physiol 259, E483-E491.

Ballèvre $\mathrm{O}$, Houlier ML, Prugnaud J, Bayle G, Bercovici D, Sève B \& Arnal M (1991) Altered partition of threonine metabolism in pigs by protein-free feeding or starvation. Am $J$ Physiol 261, E748-E757.

Bertolo RFP, Chen CZL, Law G, Pencharz PB \& Ball RO (1998) Threonine requirement of neonatal piglets receiving total parenteral nutrition is considerably lower than that of piglets receiving an identical diet intragastrically. $J$ Nutr 128, 1752-1759.

Bikker P, Verstegen MWA \& Bosh MW (1994) Amino acid composition of growing pigs is affected by protein and energy intake. $J$ Nutr $\mathbf{1 2 4}$, 1961-1969.

Darcy-Vrillon B, Souffrant WB, Laplace JP, et al. (1991) Exogenous and endogenous contributions to nitrogen fluxes in the digestive tract of pigs fed a casein diet. II. Ileal and faecal digestibilities and absorption of amino acids. Reprod Nutr Dev 31, 561-573.

Darling PB, Grunow J, Rafii M, Brookes S, Ball RO \& Pencharz PB (2000) Threonine dehydrogenase pathway of threonine catabolism in adult humans. Am J Physiol 278, E877-E884.

Davis AT \& Austic RE (1982) Threonine-degrading enzymes in the chicken. Poult Sci 61, 2107-2111.

Deutz NE, Welters CFM \& Soeters PB (1996) Intragastric bolus feeding of meals containing elementary, partially hydrolyzed or intact protein causes comparable changes in interorgan substrate flux in the pig. Clin Nutr 15, 119-128.

Fuller MF, McWilliam R, Wang TC \& Giles LR (1989) The optimum dietary amino acid pattern for growing pigs 2 . Requirements for maintenance and for tissue protein accretion. Br J Nutr 62, 255-267.

Le Floc'h N, Mézière N \& Sève B (1999) Whole blood and plasma amino acid transfers across the portal drained viscera and liver of the pig. Reprod Nutr Dev 39, 433-442.

Le Floc'h N, Obled C \& Sève B (1995) In vivo threonine oxidation rate is dependent on threonine dietary supply in growing pigs fed low to adequate levels. J Nutr 125, 2550-2562.

Le Floc'h N, Obled C \& Sève B (1996) In vivo threonine oxidation in growing pigs fed on diets with graded levels of threonine. $\mathrm{Br} J$ Nutr $\mathbf{7 5}, 825-837$.

Le Floc'h N, Sève B \& Henry Y (1994) The addition of glutamic acid or protein to a threonine-deficient diet differentially affects growth performance and threonine dehydrogenase activity in fattening pigs. J Nutr 124, 1987-1995.

Le Floc'h N, Thibault JN \& Sève B (1997) Tissue localization of threonine oxidation in pigs. Br J Nutr 77, 593-603.

MacRae JC, Bruce LA, Brown DS \& Calder AG (1997) Amino acid use by the gastrointestinal tract of sheep given lucerne forage. Am J Physiol 273, G1200-G1207.

MacRae JC, Bruce LA, Brown DS, Farningham DA \& Franklin M (1997) Absorption of amino acids from the intestine and their net flux across the mesenteric- and portal-drained viscera of lambs. J Anim Sci 75, 3307-3314.

Mantle M \& Allen A (1981) Isolation and characterization of the highmolecular-weight glycoprotein from pig colonic mucus. Biochem $J$ 173, 569-578.
Marshall T \& Allen A (1978) Isolation and characterization of the native glycoprotein from pig small-intestinal mucus. Biochem $J \mathbf{1 9 5}$, $267-275$.

Myrie SB, Bertolo RFP, Sauer WC \& Ball RO (2003) Threonine retention is reduced in diets that increase mucin production in pigs. In Proceedings of the 9th International Symposium on Digestive Physiology in Pigs, pp. 250-252 [RO Ball, editor]. Banff: University of Alberta.

Rérat A, Simoes-Nunes C, Mendy F, Vaissade P \& Vaugelade P (1992) Splanchnic fluxes of amino acids after duodenal infusion of carbohydrate solutions containing free amino acids or oligopeptides in the non-anaesthetized pig. Br J Nutr 68, 111-138.

Rérat A, Vaissade P \& Vaugelade P (1988) Quantitative measurement of endogenous amino acid absorption in unanaesthetized pigs. Arch Tierernahr 38, 463-479.

Sawadogo ML (1997) Rendements d'utilisation des acides aminé s pour l'accrétion protéique: influence d'une variation de l'apport alimentaire de thréonine et de tryptophane chez le porc. PhD Thesis, Ecole Nationale Agronomique de Rennes, France.

Sève B (1994) Alimentation du porc en croissance: intégration des concepts de protéine idéale, de disponibilité digestive des acides aminés et d'énergie nette. INRA Prod Anim 7, 275-291.

Sève B, Ballèvre O, Ganier P, Noblet J, Prugnaud J \& Obled C (1993) Recombinant porcine somatotropin and dietary protein enhance protein synthesis in growing pigs. J Nutr 123, 529-540.

Simoes-Nunes C, Galibois I, Rérat A, Savoie L \& Vaugelade P (1991) Hepatic and portal-drained viscera balances of amino acids, insulin, glucagon and gastrin in the pig after ingestion of casein or rapeseed proteins. Reprod Nutr Dev 31, 217-231.

Stoll B, Burrin DG, Henry J, Jahoor F \& Reeds PJ (1997) Phenylalanine utilization by the gut and liver measured with intravenous and intragastric tracers in pigs. Am $J$ Physiol 273, G1208-G1217.

Stoll B, Burrin DG, Henry JF, Jahoor F \& Reeds PJ (1999) Dietary and systemic phenylalanine utilization for mucosal and hepatic constitutive protein synthesis in pigs. Am J Physiol 276, G49-G57.

Stoll B, Henry J, Reeds PJ, Yu H, Jahoor F \& Burrin DG (1998) Catabolism dominates the first-pass intestinal metabolism of dietary essential amino acids in milk protein-fed piglets. $J$ Nutr $\mathbf{1 2 8}$, 606-614.

van der Schoor SR, Reeds PJ, Stoll B, Henry JF, Rosenberger JR, Burrin DG \& van Goudoever JB (2002) The high metabolic cost of a functional gut. Gastroenterology 123, 1931-1940.

Wu G (1998) Intestinal mucosal amino acid catabolism. J Nutr 128, $1249-1252$

Yamashita K \& Ashida K (1971) Effect of excessive levels of lysine and threonine on the metabolism of these amino acids in rats. J Nutr 101, 1607-1613.

Yu F, Bruce LA, Calder AG, Milne E, Coop RL, Jackson F, Horgan GW \& MacRae JC (2000) Subclinical infection with the nematode Trichostrongylus colubriformis increases gastrointestinal tract leucine metabolism and reduces availability of leucine for other tissues. J Anim Sci 78, 380-390.

Yu YM, Wagner DA, Tredget EE, Walaszewki JA, Burke JF \& Young VR (1990) Quantitative role of splanchnic region in leucine metabolism: $1-\left[1-{ }^{13} \mathrm{C},{ }^{15} \mathrm{~N}\right]$ leucine and substrate balance studies. Am J Physiol 259, E36-E51. 


\section{Appendix}

All calculations are made with the assumptions of steady state assuming that the sum of fluxes arriving in the tissue equals the sum of fluxes leaving the tissue.

$\left[1-{ }^{13} \mathrm{C}\right]$ Threonine balance during intravenous infusion

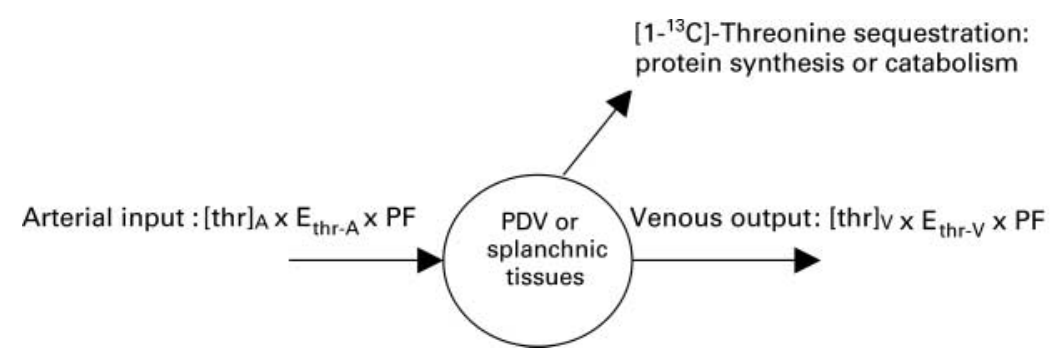

$\left[1-{ }^{13} \mathrm{C}\right]$ Threonine balance $=\left([\mathrm{thr}]_{\mathrm{V}} \times \mathrm{E}_{\mathrm{thr}-\mathrm{v}}-[\mathrm{thr}]_{\mathrm{A}} \times \mathrm{E}_{\mathrm{thr}-\mathrm{A}}\right) \times \mathrm{PF}=\left[1-{ }^{13} \mathrm{C}\right]$ threonine sequestration by the tissues (tracer recycled from artery)

This equation is valid if we assume that $\left[1-{ }^{13} \mathrm{C}\right]$ threonine recycled from labelled protein could be neglected.

$\left[1-{ }^{13} \mathrm{C}\right]$ Threonine balance during intraduodenal infusion

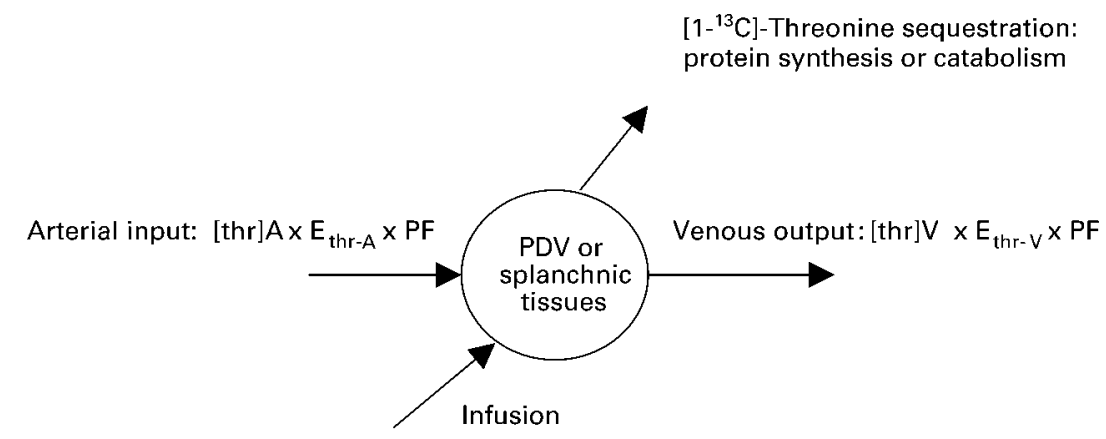

$\left[1-{ }^{13} \mathrm{C}\right]$ Threonine balance $=\left([\mathrm{thr}]_{\mathrm{V}} \times \mathrm{E}_{\mathrm{thr}-\mathrm{V}}-[\mathrm{thr}]_{\mathrm{A}} \times \mathrm{E}_{\mathrm{thr}-\mathrm{A}}\right) \times \mathrm{PF}$

$=$ infusion $-\left[1{ }^{13} \mathrm{C}\right]$ threonine sequestration by the tissues (tracer from infusion and recycled from artery)

$=$ newly infused $\left[1-{ }^{13} \mathrm{C}\right]$ threonine appearance in the efferent plasma - arterial $\left[1-{ }^{13} \mathrm{C}\right]$ threonine sequestration by the tissues

$\left[1-{ }^{13} \mathrm{C}\right]$ Threonine liver balance

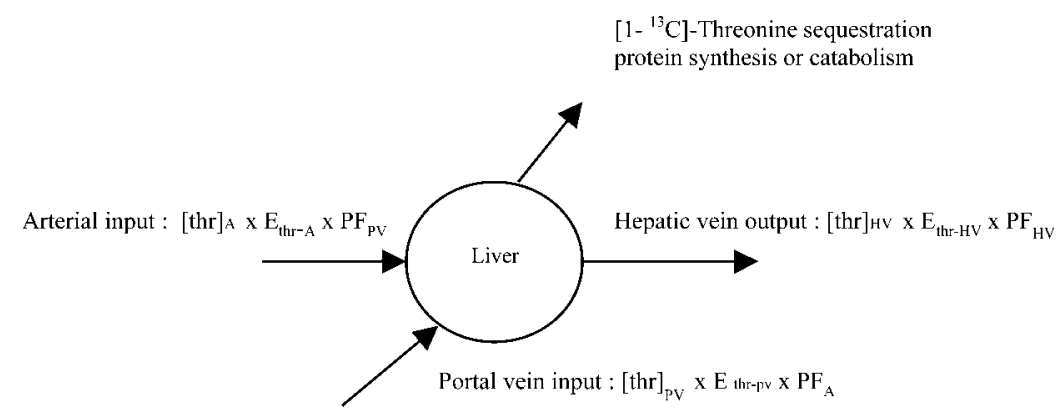

$\left[1-{ }^{13} \mathrm{C}\right]$ Threonine balance $=[\mathrm{thr}]_{\mathrm{HV}} \times \mathrm{E}_{\mathrm{thr}-\mathrm{Hv}} \times \mathrm{PF}_{\mathrm{HV}}-\left([\mathrm{thr}]_{\mathrm{PV}} \times \mathrm{E}_{\mathrm{thr}-\mathrm{PV}} \times \mathrm{PF}_{\mathrm{PV}}+[\mathrm{thr}]_{\mathrm{A}} \times \mathrm{E}_{\mathrm{thr}-\mathrm{A}} \times \mathrm{PF}_{\mathrm{A}}\right)$ $=\left[1-{ }^{13} \mathrm{C}\right]$ threonine sequestration by the tissues (tracer from portal vein and recycled from artery) 